Валентин Юрійович Мазур (канд. військ. наук, доцент)

Олег Васильович Боровик (оокт. техн. наук, професор)

Національна академія Державної прикордонної служби Украӥни імені Богдана Хмельницького, Хмельницький, Украйна

\title{
КОНЦЕПЦІЯ РОЗБУДОВИ ЄДИНОЇ СИСТЕМИ ВИСВІТЛЕННЯ НАДВОДНОЇ ОБСТАНОВКИ НА МОРСЬКІЙ (РІЧКОВІЙ) ДІЛЯНЦІ В КОНТЕКСТІ ЗАБЕЗПЕЧЕННЯ ПРИКОРДОННОЇ БЕЗПЕКИ
}

Специфічним і важливим видом національної безпеки є прикордонна безпека. Актуальними на даний час завданнями для Держприкордонслужби Украӥни є: забезпечення розвитку інтегрованого управління кордонами з урахуванням досвіду держав - членів Свропейського Союзу; підвищення рівня боєздатності органів Держприкордонслужби та їх спроможності до виконання завдань із захисту державного кордону; забезпечення готовності до охорони тимчасово неконтрольованих ділянок державного кордону після відновлення контролю над ними; підвищення рівня довіри населення до Держприкордонслужби та ї̈ особового складу. Реалізащія иих завдань залежить від можливості вирімення ряду часткових завдань, одним з яких $\epsilon$ забезпечення розвитку Морської охорони Держприкордонслужби. Можливість вирішення цьього завдання залежить від наявності та якості функиіонування системи висвітлення надводної обстановки на морській (річковій) ділянці.

У роботі подано концепцію розбудови системи висвітлення надводної обстановки Державної прикордонної служби Украӥни на морській (річковій) ділянці в контексті забезпечення прикордонної безпеки. Формування конщепції базувалося на раніме проведених авторами дослідженнях стосовно методичних основ реалізації цьього завдання та функціональному аналізі можливих варіантів розбудови системи й обтрунтуванні доцільності вибору і реалізації одного з них.

Ключові слова: концепція, система висвітлення надводної обстановки, Державна прикордонна служба Украӥни, прикордонна безпека, розбудова.

\section{Вступ}

Специфічним і важливим видом національної безпеки $\epsilon$ прикордонна безпека, яка повинна дозволяти захищати інтереси особистості, суспільства i держави у прикордонній сфері. Основні завдання в сфері прикордонної безпеки забезпечення недоторканності державного кордону та охорони суверенних прав України в іiі виключній (морській) економічній зоні, покладаються на Державну прикордонну службу України (ДПСУ) [1]. Головні завдання, основні функції i принципи діяльності ДПСУ визначаються статтями 1-3 Закону України [1]. Основні напрями розвитку прикордонного відомства на найближчий період визначаються Стратегією розвитку [2] та Концепцією інтегрованого управління кордонами [3]. Згідно цих документів актуальними на даний час завданнями для ДПСУ вбачаються: забезпечення розвитку інтегрованого управління кордонами 3 урахуванням досвіду держав - членів Європейського Союзу; підвищення рівня боєздатності органів Держприкордонслужби та їх спроможності до виконання завдань із захисту державного кордону; забезпечення готовності до охорони тимчасово неконтрольованих ділянок державного кордону після відновлення контролю над ними; підвищення рівня довіри населення до ДПСУ та ії особового складу.

Постановка проблеми. Реалізація цих завдань залежить від можливості вирішення ряду часткових завдань, окремими 3 яких є створення системи інтегрованого управління безпекою державного кордону та забезпечення розвитку Морської охорони Держприкордонслужби. Можливість вирішення останніх залежить від наявності та якості функціонування системи висвітлення надводної обстановки на морській (річковій) ділянці (СВНО). На це вказує той факт, що загальна протяжність державного кордону України становить 6992,982 км, 3 них загальна довжина морського кордону становить 1355 км. Тобто, майже 20\% державного кордону України проходить по морю. Оскільки ж ефективність охорони морської (річкової) ділянки державного кордону залежить від якісного функціонування CВНО, то це i підтверджує висновок про причинно-наслідкову залежність розвитку Морської охорони ДПСУ від розбудови СВНО.

Аналіз остатніх досліджень і публікацій. Стан існуючої СВНО ДПСУ $є$ незадовільним. На це вказують норми, положення, рішення, що наведені в документах [4-13], а також відсутність наукових досліджень, які б проводилися у прикордонному відомстві та стосувалися б питань забезпечення достатньої ефективності функціонування Морської охорони ДПСУ. Більше того, на даний час відсутні і концептуальні документи, які б регламентували напрями розвитку Морської охорони, загалом, i СВНО, зокрема.

Зважаючи на це, автори у роботах [14-15] приділили увагу питанням формування 
методичних основ створення концепції розбудови СВНО ДПСУ, функціонального аналізу варіантів створення єдиної СВНО та обгрунтуванню варіанту розбудови, який був би доцільним для запровадження в контексті забезпечення прикордонної безпеки. Однак у цих працях сама концепція не була сформована.

Метою статті $\epsilon$ безпосередньо формування концепції розбудови системи висвітлення надводної обстановки на морській (річковій) ділянці в контексті забезпечення прикордонної безпеки.

Виклад основного матеріалу дослідження.

Слід відмітити, що методична база для формування концепції наведена у працях [14-15]. Враховуючи іiі, концепцію можна представити в наступному вигляді.

Загальні положення. Концепція створення єдиної системи висвітлення надводної обстановки (ССВНО) в акваторіях Чорного і Азовського морів та басейнами річок Дніпро і Дунай з міжвідомчим морським центром в м. Одеса (далі - Концепція) розроблена на виконання вимог Закону України «Про оборону України» (зі змінами та доповненнями), Указу Президента України № 555/2015 від 24 вересня 2015 року про уведення в дію рішення Ради національної безпеки і оборони України від 2 вересня 2015 року «Про нову редакцію Воєнної доктрини України», та розпорядження Кабінету Міністрів України від 11 листопада 2015 року № 1179-р «Про схвалення Концепції Державної цільової правоохоронної програми «Облаштування та реконструкція державного кордону» на період до 2020 року».

Актуальність створення ССВНО в акваторіях Чорного і Азовського морів та басейнами річок Дніпро i Дунай обумовлена загрозами воєнній безпеці України, серед яких:

активна дестабілізуюча зовнішня політика Російської Федерації щодо сусідніх держав;

- територіальні претензії Російської Федерації до України і посягання на їі суверенітет та територіальну цілісність;

- повномасштабна збройна агресія Російської Федерації проти України 3 проведенням, в тому числі, морських операцій 3 рішучими воєнно-політичними цілями;

гальмування процесу договірно-правового оформлення державних кордонів та розмежування виключних (морських) економічних зон i континентального шельфу між державами;

- розширення масштабів тероризму, піратства, інших явищ, пов'язаних із застосуванням збройного насильства;

блокада морських портів, узбережжя або повітряного простору України із застосуванням воєнної сили, порушення морських комунікацій України з боку Російської Федерації.

1. Мета Концепції

Метою Концепції є: визначення структури єдиної системи висвітлення надводної обстановки в акваторіях Чорного i Азовського морів та басейнами річок Дніпро i Дунай, основних завдань, шляхів організації робіт зі створення i подальшого розвитку постійного моніторингу надводної i підводної обстановки, як в Чорноморській і Азовській військово-морських зонах відповідальності, так і в басейнах річок Дніпро і Дунай силами та засобами ВійськовоМорських Сил Збройних Сил України, Державної прикордонної служби України, Міністерства інфраструктури України та Державного рибного агентства України; створення міжвідомчого морського центру.

2. Визначення основних понять, що застосовуються в Концепції

Чорноморська i Азовська військово-морські зони відповідальності (далі морські зони відповідальності) - морський простір 3 урахуванням правового статусу тимчасово окупованих територій внутрішніх морських вод i територіального моря України навколо Кримського півострова i окремого району Донецької області.

Басейни річок - суднохідні ділянки річок в приморській частини країни.

Засоби виявлення та спостереження - всі технічні засоби виявлення надводних, низьколетячих та підводних об'єктів, що стоять на озброєнні, оснащенні (можуть бути прийняті на озброєння, оснащення) Військово-Морських Сил Збройних Сил України, Державної прикордонної служби України, Міністерства інфраструктури України та Державного агентства рибного господарства України, й використовують різні фізичні принципи дії та способи для отримання інформації про об'єкти спостереження.

Об'єкти спостереження - всі плавзасоби, підводні човни, засоби доставки підводнодиверсійних сил та засобів, біологічні об’єкти, повітряні об’єкти на висоті до 1000 метрів, що знаходяться в зоні спостереження державної інтегрованої інформаційної системи висвітлення надводної і підводної обстановки.

Суб'єкти ЄСВНО в акваторіях Чорного i Азовського морів та басейнах річок Дніпро i Дунай - військові частини та підрозділи, пункти управління Військово-Морських Сил Збройних Сил України, управління прикордонних загонів та пости технічного спостереження Державної прикордонної служби України, структурні підрозділи державної установи «Держгідрографія», державної установи «Дельталоцман», казенного підприємства «Морська пошуково-рятувальна служба» Міністерства інфраструктури України, Державного агентства рибного господарства України.

3. Загальна характеристика i основні положення

ССВНО в акваторіях Чорного i Азовського морів та басейнами річок Дніпро i Дунай призначена для:

- забезпечення морської діяльності України комплексною інформацією, отриманою від інформаційних систем відомств та міністерств України;

- постійного моніторингу надводної, 
підводної обстановки в ближній, середній та дальній зонах спостереження, здійснення ідентифікації виявлених об'єктів, визначення параметрів їх руху, аналізу, збору та узагальнення отриманої інформації з ії подальшою трансляцією до Головного ситуаційного центру України та пунктів управління (центрів) суб'єктів ЄСВНО в акваторії Чорного і Азовського морів та басейнах річок Дніпро і Дунай;

- забезпечення Головного ситуаційного центру України, міжвідомчого морського центру з місцем дислокації м. Одеса даними про морську обстановку, командних пунктів військовоморських баз, з'єднань, тактичних груп кораблів, військових частин та підрозділів Збройних Сил України, інших суб'єктів ЄСВНО в акваторіях Чорного i Азовського морів та басейнах річок Дніпро і Дунай даними про морську обстановку в частині, що стосується.

Єдина система містить отримані дані за результатами спостережень, вимірювань і досліджень відомості про стан морського середовища, природних ресурсів, в Чорному та Азовському морях, на островах, прибережних територіях, відомості про морський транспорт промислового рибальства, видобутку корисних копалин, інших видів морської діяльності, соціально-економічну та іншу інформацію, необхідну для вивчення і використання ресурсів Світового океану і контролю за його станом.

Функціонування ЄСВНО забезпечується шляхом інтеграції та раціонального використання засобів, що здійснюють збір, обробку, накопичення, зберігання, захист та поширення інформації про обстановку в Чорному та Азовському морях.

Структурно ЄСВНО включає в себе підсистеми висвітлення надводної та повітряної обстановки, висвітлення підводної і радіоелектронної обстановки, зв'язку та передачі даних й складається 3 наступних стаціонарних та мобільних компонентів Військово-Морських Сил Збройних Сил України; Державної прикордонної служби України; державної установи «Держгідрографія» Міністерства інфраструктури України; державної установи «Дельта-лоцман» Міністерства інфраструктури України, казенного підприємства «Морська пошуково-рятувальна служба» Міністерства інфраструктури України, Державного агентства рибного господарства України.

Підсистема висвітлення повітряної та надводної обстановки складається 3 засобів виявлення та спостереження, що належать Військово-Морським Силам Збройних Сил України, Державній прикордонній службі України, Міністерству інфраструктури України та Державному агентству рибного господарства України у стаціонарному або мобільному варіантах виготовлення, які розташовуються в залежності від особливостей району, завдань інформаційного забезпечення, а також своїх потенційних можливостей на даному напрямку.

Підсистема висвітлення підводної радіоелектронної обстановки складається 3 засобів висвітлення підводної обстановки, що належать Військово-Морським Силам Збройних Сил України.

Підсистема зв'язку та передачі даних складається із завадозахищених комунікаційних мереж суб'єктів ЄCВНО в акваторіях Чорного і Азовського морів та басейнах річок Дніпро і Дунай $з$ центральним та дублюючим сервером на базі Військово-Морських Сил Збройних Сил України.

Концепція впроваджується шляхом видання Постанови Кабінету Міністрів України.

4. Основні напрями створення ЄСВНО в акваторіях Чорного і Азовського морів та басейнах річок Дніпро і Дунай:

реалізація єдиних поглядів i технічних підходів щодо організаційної структури системи, взаємодія між міністерствами, іншими центральними органами виконавчої влади, державними i недержавними структурами стосовно отримання необхідної інформації про морську обстановку;

- реалізація поєднання підсистем висвітлення надводної, підводної та радіоелектронної обстановки в єдиній системі висвітлення обстановки;

розроблення оперативно-тактичних i тактико-технічних вимог до системи висвітлення та іiі складових частин з урахуванням підходів усіх зацікавлених сторін;

визначення необхідного складу існуючих і перспективних засобів висвітлення морської обстановки в морських зонах відповідальності;

визначення структури та складу засобів інтегрованої автоматизованої системи збирання, обробки та порядку передачі добутої інформації від засобів висвітлення морської обстановки до суб'єктів єдиної державної інтегрованої інформаційної системи висвітлення надводної i підводної обстановки в акваторіях Чорного і Азовського морів та басейнах річок Дніпро і Дунай;

створення WEB-порталу для цивільних споживачів з визначеним обсягом інформації.

5. Основні вимоги до ЄСВНО в акваторіях Чорного i Азовського морів та басейнах річок Дніпро і Дунай:

неперервність діяльності в часі та просторі в зоні спостереження;

- відповідність показників ефективності системи меті створення;

функціонування системи в масштабі часу, близькому до реального;

спроможність забезпечити використання зброї по виявлених цілях у морських зонах відповідальності за даними системи;

- централізація управління системою зі збереженням елементів децентралізації на суб'єктових рівнях;

можливість реконфігурації системи та іiі елементів під завдання, що виникають при змінах обстановки в морських зонах відповідальності;

- достатність визначеного складу засобів висвітлення морської обстановки;

- завадозахищеність як окремих засобів 
висвітлення морської обстановки, так і системи в цілому, а також каналів обміну та передачі інформації;

- модернізаційні можливості засобів висвітлення морської обстановки, передачі та обробки інформації;

- електромагнітна та гідроакустична сумісність складових елементів системи; перспективна сумісність системи 3 аналогічними системами регіональних партнерів та структурами командування НАТО (за допомогою Об'єднаного командування ВМС НАТО) для обміну інформацією про обстановку в автоматизованому режимі; системи. екологічна безпека функціонування

6. Зональний розподіл ЄСВНО в акваторіях Чорного i Азовського морів та басейнах річок Дніпро і Дунай

Система має виявляти різнотипні цілі (всі існуючі типи плавзасобів, підводні човни, засоби доставки підводно-диверсійних сил та засобів, біологічні об'єкти, повітряні об'єкти на висоті до 1000 метрів) в межах дальньої, середньої та ближньої зон, а саме:

в ближній зоні - в межах до 12 миль $\mathrm{i}$ співпадати з зоною територіальних вод України;

- в середній зоні - в межах від 12 до 30 миль від берегової смуги України;

в дальній зоні - в межах від 30 до 220 миль від берегової смуги України, яка починається 3 дальньої межі середньої зони, що обмежена можливостями засобів висвітлення надводної обстановки i, 3 урахуванням дальності дії загоризонтних радіолокаційних станцій.

7. Етапи створення системи та основні завдання за етапами

I етап - створення центрального та дублюючого серверів, інтегрування існуючих систем Військово-Морських Сил Збройних Сил України та Державної прикордонної служби України в спільну інтегровану інформаційну систему висвітлення обстановки;

II етап - створення міжвідомчого морського центру в м. Одеса, об'єднання всіх наявних відомчих систем держави у єдину інтегровану інформаційну систему висвітлення обстановки в міжвідомчому морському центрі та видачею інформації до Головного ситуаційного центру України;

III етап:

- створення WEB-порталу ЄСВНО, забезпечення спроможності системи висвітлення

\section{Лimepamypa}

1. Про Державну прикордонну службу України: Закон України № 6612-IV від 3 квітня 2003 р. // Відомості Верховної Ради. - 2003. - № 27. - С. 208. 2. Стратегія розвитку Державної прикордонної служби: Схвалено розпорядженням Кабінету Міністрів України від 23 листопада 2015 р. № 1189-р. 3. Концепція інтегрованого управління кордонами, схвалена розпорядженням Кабінету Міністрів України від 28 жовтня 2015 р. № 1149: законодавство України, сайт Верховної ради України. - [Електронний ресурс] // Режим доступу:http //zakon3.gov.ua/laws/show/1149-2015-p\#n10 4. Закон надводної і підводної обстановки передавати відповідну відкриту інформацію регіональним партнерам та структурам командування НАТО (за допомогою Об'єднаного командування ВМС НАТO);

- модернізація системи та нарощення спроможності постів спостереження (встановлення загоризонтних РЛС) вздовж узбережжя Чорного i Азовського морів та басейнів річок Дніпро i Дунай;

- установка комерційних автоматичних систем ідентифікації (приймачі AIC) на військових кораблях;

встановлення автоматичних систем ідентифікації (розпізнавання) для бойових кораблів відповідно до стандартів НАТО.

8. Фінансування робіт зі створення системи

Фінансування робіт зі створення системи здійснюється відповідно до вимог чинного законодавства України в межах асигнувань та за рахунок міжнародної фінансової допомоги.

9. Очікувані результати

Створення системи дасть можливість:

- отримувати інформацію про морську обстановку в морських операційних зонах (на ділянці відповідальості) у масштабі часу, близькому до реального;

- здійснювати оперативне забезпечення протидесантної, протикорабельної, протичовнової та протипідводно-диверсійної оборони узбережжя, портів, пунктів базування ВМС ЗС України, місць стоянки кораблів та суден, районів видобутку корисних копалин, маршрутів руху пересування кораблів і суден;

- посилити охорону державного кордону України та виключної (морської) економічної зони України;

здійснювати моніторинг надводної та підводної обстановки, виявляти аномальні явища та випадки техногенного характеру в морському середовищі, які можуть призвести до екологічних катастроф;

- координувати проведення пошуковорятувальних операцій.

\section{Висновки й перспективи подальших досліджень}

Таким чином, авторські дослідження дозволили сформувати Концепцію розбудови єдиної системи висвітлення надводної обстановки, реалізація якої могла б забезпечити достатній рівень прикордонної безпеки. Напрямками подальших досліджень є SWOT-аналіз наведеної Концепції.

України «Про виключну (морську) економічну зону України». 5. Конвенція Організації Об'єднаних Націй по морському праву - Нью-Йорк, видавництво ООН. 6. Договір між Україною та Російською Федерацією про співробітництво у використанні Азовського моря та Керченської протоки. 7. Постанова Кабінету Міністрів України «Про затвердження Положення про порядок охорони суверенних прав України у іiі виключній (морській) економічній зоні». 8. Постанова Кабінету Міністрів України «Про затвердження правил плавання i перебування в територіальному морі, внутрішніх водах і 
на рейдах та в портах України іноземних військових кораблів». 9. Розпорядження Президента України «Про охорону державного кордону України в Азовському та Чорному морях і Керченській протоці та забезпечення прав України в її виключній (морській) економічній зоні та континентальному шельфі у північно - східній частині Чорного моря». 10. Наказ Адміністрації Державної прикордонної служби України від 02.07.10 № 506 «Про організацію системи моніторингу державного кордону». 11. Наказ Голови Держкомітету «Про затвердження Порадника зі служби Морської охорони ПВУ (ПС МО ПВУ - 99)» від 30 квітня 1999 року № 200. 12. Наказ Голови Держкомітету «По спостереженню, оповіщенням та донесенням на морській ділянці державного кордону i у виключній (морській) економічній зоні» від 17.12.1997 року № 460 . 13. Жибарев М.Є. Охорону морського кордону - на рівень сучасних вимог. Науковий вісник ДПС України. 2005. - № 3. - с.18-27. 14. Мазур В. Ю. Методичні основи формування концепції розбудови системи висвітлення надводної обстановки на морській (річковій) ділянці в контексті забезпечення прикордонної безпеки / Мазур В. Ю., Боровик О. В.// Сучасні інформаційні технології у сфері безпеки та оборони № 3 (30) - К., 2017. - С. 12 - 20. 15. Мазур В. Ю., Боровик О. В. Функціональний аналіз варіантів створення єдиної системи висвітлення надводної обстановки на морській (річковій) ділянці в контексті забезпечення прикордонної безпеки Збірник наукових праць Національної академії Державної прикордонної служби України. Серія : військові та технічні науки : наукове видання / [гол. ред. Олексієнко Б. М.]. Хмельницький : Видавництво НАДПСУ, 2017. - № 4(74). - C. $126-138$.

\title{
КОНЦЕПЦИЯ РАЗВИТИЯ ЕДИНОЙ СИСТЕМЫ ОСВЕЩЕНИЯ НАДВОДНОЙ ОБСТАНОВКИ НА МОРСКОМ (РЕЧНОМ) УЧАСТКЕ В КОНТЕКСТЕ ОБЕСПЕЧЕНИЯ ПОГРАНИЧНОЙ БЕЗОПАСНОСТИ
}

\author{
Валентин Юриевич Мазур (канд. воен. наук, доцент)
}

Олег Васильевич Боровик (докт. техн. наук, профессор

\section{Национальная академия Государственной пограничной службы Украины имени Богдана Хмельницкого, Хмельницкий, Украина}

Специифическим и важным видом наџиональной безопасности есть пограничная безопасность.

Актуальными в данное время задачами для Государственной пограничной службы Украины есть: обеспечение развития интегрированного управления границами с учетом опыта государств-членов Европейского Союза; повышение уровня боеспособности органов Госпогранслужбы, а также их возможности к выполнению задач по защите государственной гранищы; обеспечение готовности к охране временно неконтролируемых участков государственной границы после восстановления контроля над ними ;повышение уровня доверия населения к Госпогранслужбе и ее личному составу. Реализаџия этих задач зависит от возможности решения ряда частных задач, одной из которых есть обеспечение развития Морской охраны Госпогранслужбы. Возможность решения этого задания зависит от наличия и качества функиионирования системы освещения надводной обстановки на морском (речном) участке.

В работе представлено концепцию развития системы освещения надводной обстановки Государственной пограничной службы Украины на морском (речном) участке в контексте обеспечения пограничной безопасности. Формирование концепции базировалось на ранее проведенных авторами исследованиях относительно методических основ реализации этого задания и функциональном анализе возможных вариантов построения системы, а также обоснованности выбора иелесообразности выбора и реализации одного из них.

Ключевые слова: концепџия, система освещения надводной обстановки, Государственная пограничная служба Украины, пограничная безопасность, развитие.

\section{THE CONCEPT OF DEVELOPMENT OF A UNIFIED SYSTEM OF THE SEA (RIVER) SECTOR SURFACE PICTURE DISPLAY IN THE CONTEXT OF BORDER SECURITY ENSURING}

Valentyn Yuriiovych Mazur (Candidate of Military Science, Associate Professor) Oleh Vasyliovych Borovyk (Doctor of Engineering Science, Professor)

\section{Bohdan Khmelnytskyi National Academy of the State Border Guard Service of Ukraine, Khmelnytskyi, Ukraine}

Border security is a specific and important type of national security.

The current tasks for the State Border Guard Service of Ukraine are: to ensure the development of integrated border management taking into account the experience of the member states of the European Union; to increase the level of combat readiness of the bodies of the State Border Service, as well as their ability to perform tasks concerning the state border protection; to ensure readiness for the protection of temporarily uncontrolled sectors of the state border after the restoration of control over them; to increase the level of public confidence in the State Border Service and its personnel. The implementation of these tasks depends on the possibility of solving a number of particular problems, one of which is to ensure the development of the Maritime Guard of the State Border Guard Service. The possibility of solving this task depends on the availability and quality of the functioning of the system of the sea (river) sector surface picture display.

The paper presents the concept of development of a system of the sea (river) sector surface picture display of the State Border Guard Service of Ukraine in the context of border security ensuring. Formation of 
the concept was based on earlier studies carried out by the authors on the methodological foundations for implementing this task and a functional analysis of possible options for the system development, as well as the reasonableness of the choice of the expediency of selecting and implementing one of them.

Key words: concept, system of surface picture display, State Border Guard Service of Ukraine, border security, development.

\section{References}

1. The Law of Ukraine (2003) "On the State Border Guard Service of Ukraine" [Pro Derzhavnu prykordonnu sluzhbu Ukrainy]: Zakon Ukrainy No. 6612-IV 03.04.2003. // Vidomosti Verkhovnoi Rady. - 2003. - No. 27. - p. 208. 2. The Development Strategy of the State Border Guard Service of Ukraine (2015) [Stratehiia rozvytku Derzhavnoi prykordonnoi sluzhby]: Approved by the Order of the Cabinet of Ministers of Ukraine [Skhvaleno rozporiadzhenniam Kabinetu Ministriv Ukrainy] 23.11.2015 No. 1189-r. 3. The Concept of integrated border management (2015) [Kontseptsiia intehrovanoho upravlinnia kordonamy], Approved by the Order of the Cabinet of Ministers of Ukraine [Skhvaleno rozporiadzhenniam Kabinetu Ministriv Ukrainy] 28.10.2015 No. 1149: zakonodavstvo Ukrainy, sait Verkhovnoi rady Ukrainy. - [Elektronnyi resurs] // URL: http//zakon3.gov.ua/laws/show/1149-2015-p\#n10. 4. The Law of Ukraine "On Exclusive (marine) Economic Zone of Ukraine" [Zakon Ukrainy «Pro vykliuchnu (morsku) ekonomichnu zonu Ukrainy»]. 5. UN Convention on the Law of the Sea (1982) [Konventsiia Orhanizatsii Obiednanykh Natsii po morskomu pravu] 10.12.1982 - NY, UNO Publishing House. 6. Ukrainian-Russian treaty "On cooperation in using of the Sea of Azov and Kerch strait". [Dohovir mizh Ukrainoiu ta Rosiiskoiu Federatsiieiu pro spivrobitnytstvo u vykorystanni Azovskoho moria ta Kerchenskoi protoky]. 7. The Decree of the Cabinet of Ministers of Ukraine "On Approving of the Order of the Ukrainian sovereign rights protection in the Exclusive (marine) Economic Zone" [Postanova Kabinetu Ministriv Ukrainy «Pro zatverdzhennia Polozhennia pro poriadok okhorony suverennykh prav Ukrainy u yii vykliuchnii (morskii) ekonomichnii zoni»]. 8. The Decree of the Cabinet of Ministers of Ukraine "On approving the rules of sailing and staying in the territorial sea (waters) at anchorage and in ports". [Postanova Kabinetu Ministriv Ukrainy «Pro zatverdzhennia pravyl plavannia i perebuvannia $\mathrm{v}$ terytorialnomu mori, vnutrishnikh vodakh $\mathrm{i}$ na reidakh ta $\mathrm{v}$ portakh Ukrainy inozemnykh viiskovykh korabliv»)]. 9. Decree of the President of Ukraine "On Protection of the State Border of Ukraine in the Azov and Black Seas and the Kerch Strait and ensuring the rights of Ukraine in its exclusive (maritime) economic zone and the continental shelf in the north-eastern part of the Black Sea" [Rozporiadzhennia Prezydenta Ukrainy «Pro okhoronu derzhavnoho kordonu Ukrainy v Azovskomu ta Chornomu moriakh i Kerchenskii prototsi ta zabezpechennia prav Ukrainy $\mathrm{v}$ yii vykliuchnii (morskii) ekonomichnii zoni ta kontynentalnomu shelfi u pivnichno - skhidnii chastyni Chornoho moria»]. 10. Order of the Administration of the State Border Guard Service of Ukraine (2010) "On the organization of the system of monitoring of the state border".[Nakaz Administratsii Derzhavnoi prykordonnoi sluzhby Ukrainy «Pro orhanizatsiiu systemy monitorynhu derzhavnoho kordonu»]. 02.07.2010 No. 506 11. Order of the Head of the SBGSU Administration (1999) "On Approval of the Guidelines on the Service of Marine Guard SBGTU Nakaz Holovy Derzhkomitetu" «Pro zatverdzhennia Poradnyka zi sluzhby Morskoi okhorony PVU (PS MO PVU - 99)» 30.04.1999 No. 200. 12. Order of the Head of the SBGSU Administration (1997) "On observation, notification and reporting at the maritime sector of the state border and in the exclusive (marine) economic zone " [Nakaz Holovy Derzhkomitetu «Po sposterezhenniu, opovishchenniam ta donesenniam na morskii diliantsi derzhavnoho kordonu i u vykliuchnii (morskii) ekonomichnii zoni»] 17.12.1997 No.460. 13. Zhybarev M.Ye (2005), Protection of the sea border - to the level of modern requirements [Okhoronu morskoho kordonu - na riven suchasnykh vymoh]. Naukovyi visnyk DPS Ukrainy. 2005., No. 3. - pp.18-27. 14. Mazur V. Yu., Borovyk O. V. Methodological basis of concept forming concerning development of a system of the sea (river) sector surface picture display in the context of border security ensuring [Metodychni osnovy formuvannia kontseptsii rozbudovy systemy vysvitlennia nadvodnoi obstanovky na morskii (richkovii) diliantsi v konteksti zabezpechennia prykordonnoi bezpeky], Suchasni informacijni tekhnologhiji u sferi bezpeky ta oborony, No. 30, pp. 12-20. 15. Mazur V. Yu., Borovyk O. V. Functional analysis of the options for the development of a unified system of the sea (river) surface picture display in the context of border security ensuring [Funktsionalnyi analiz variantiv stvorennia yedynoi systemy vysvitlennia nadvodnoi obstanovky na morskii (richkovii) diliantsi $\mathrm{v}$ konteksti zabezpechennia prykordonnoi bezpeky] - Zbirnyk naukovykh prats Natsionalnoi akademii Derzhavnoi prykordonnoi sluzhby Ukrainy. Seriia : viiskovi ta tekhnichni nauky : naukove vydannia / [hol. red. Oleksiienko B. M.]. - Khmelnytskyi : Vydavnytstvo NADPSU, 2017. - № 4(74). - C. 126-138. 